\title{
Effect of mesograzers and nutrient levels on induction of defenses in several Brazilian macroalgae
}

\author{
Kerstin Weidner ${ }^{1}$, Bruno G. Lages ${ }^{2}$, Bernardo A. P. da Gama ${ }^{2}$, Markus Molis ${ }^{3,4, *}$, \\ Martin Wahl ${ }^{3}$, Renato C. Pereira ${ }^{2}$ \\ ${ }^{1}$ Interdisciplinary Ecology Centre, Technical University Bergakademie Freiberg, Leipziger Straße 29, \\ 09599 Freiberg, Germany \\ ${ }^{2}$ Departamento de Biologia Marinha, Instituto de Biologia, Universidade Federal Fluminense, CP 100.644, \\ CEP 24001-970 Niterói, Rio de Janeiro, Brazil \\ ${ }^{3}$ Leibniz Institute of Marine Sciences, Marine Ecology/Marine Zoology, Düsternbrooker Weg 20, 24105 Kiel, Germany \\ ${ }^{4}$ Present address: Marine Biological Station Helgoland, Foundation Alfred Wegener Institute for Polar and Marine Research, \\ Kurpromenade 201, 27498 Helgoland, Germany
}

\begin{abstract}
Herbivory can greatly modify benthic community structure by affecting the distribution of algal species. To deter herbivores, algae have developed several mechanisms, including the induction of chemical and morphological defenses, which may be influenced by nutrient availability. We tested 4 red (Chondrophycus flagellifera, Cryptonemia seminervis, Osmundaria obtusiloba, Pterocladiella capillacea), 4 brown (Dictyota menstrualis, Lobophora variegata, Sargassum vulgare, Stypopodium zonale), and 1 green (Codium decorticatum) algae for inducible defenses following exposure to direct consumption by an amphipod community dominated by Elasmopus brasiliensis. In addition, the effects of water-borne cues from nearby grazed conspecifics and non-grazing consumers on the induction of defenses were examined in C. decorticatum under natural and enhanced (200\% natural) nutrient levels. Induction of defense was assessed in choice-feeding assays, using live algae or artificial food containing non-polar extracts of amphipod-exposed (treated) and non-exposed (control) algae. Palatability levels, estimated as the relative difference in wet mass due to consumption in feeding assays between grazer-exposed and control plants, declined significantly in 3 species after the acclimatization period. Tissue from the directly consumed red alga $P$. capillacea (live alga) was significantly less palatable than tissue from the control plants. Likewise, a significant effect was observed in the brown alga L. variegata. Similar, although not statistically significant, trends were observed in 6 other species. For the green alga $C$. decorticatum, nutrient enrichment did not affect induction of defenses by herbivores, yet unfertilized plants were more palatable than fertilized conspecifics.
\end{abstract}

KEY WORDS: Plant-animal interaction · Tropical seaweeds · Mesograzer · Nutrient enrichment • Feeding preference

Resale or republication not permitted without written consent of the publisher

\section{INTRODUCTION}

Herbivory strongly impacts the distribution of algae and thus benthic community structure (Hay 1997, Duffy \& Hay 2000) in both temperate and tropical marine environments (Hay \& Fenical 1988). On coral reefs for example, herbivores can remove almost $100 \%$ of macroalgal production (Hay \& Steinberg 1992, Paul et al. 2001). To persist against natural enemies, algae must escape, tolerate or deter them (Hay \& Fenical 1988, Duffy \& Hay 1991).

Besides nutritional and associational defenses, chemical and morphological defenses are the most common mechanisms used by macroalgae to deter herbivores, and make algae active participants in grazer-alga interactions (Cronin 2001). Yet it has been 
suggested that defenses are costly and can only be achieved by diverting materials and energy from other life processes such as growth or reproduction (Cronin 2001). For such a mechanism to evolve, the benefits of defenses should increase fitness more than the costs reduce fitness.

Constitutive defenses require expenditure of resources even when consumers are absent. In contrast, inducible defenses allow defense-associated costs, if any, to be deferred until consumers have been detected, at which time the costs will be offset by the benefits of protection (Cronin \& Hay 1996c). Besides this presumed advantage of increased resource availability for other plant processes when the defense is not induced, induction also creates variability in food quality and therefore hinders herbivores in their adaptation to host plants (Agrawal \& Karban 1999). Furthermore, plants that can induce defenses are less exposed to the potential autotoxic effects of storing deterrent secondary metabolites when they are not required (Agrawal \& Karban 1999). Inducible defenses should be favored when defense chemicals are costly to produce, the presence of the consumers is variable and unpredictable over temporal and spatial scales, and when individual plants are longer lived than their consumers (Pavia \& Toth 2000). Furthermore, reliable cues (visual/physical contact, water-borne signals) like herbivory must be present in the environment (Toth \& Pavia 2000, Sotka et al. 2002).

There is considerably less evidence of herbivoreinduced defensive responses in marine macroalgae (e.g. Paul \& Van Alstyne 1992, Yates \& Peckol 1993, Cronin \& Hay 1996c, Hammerstrom et al. 1998, Pavia \& Brock 2000) compared to terrestrial plants. This inconsistency could be explained by the lack of an efficient transport system in non-vascular algae to translocate the induction stimulus throughout the algae, or simply be due to the comparatively small amount of research effort in marine systems (Cronin \& Hay 1996c).

Because mesograzers are ubiquitous herbivores with rapid population growth in nearly all vegetated habitats, Duffy \& Hay (2000) argued that they could have important impacts on plant assemblages, despite their low mobility and biomass consumption compared to large herbivores such as fishes. Mesograzers consume small amounts of algae over extended periods, which might allow the algae to respond to their attack (Cronin \& Hay 1996c).

Most chemical deterrents produced by algae are lipid-soluble secondary metabolites (Hay \& Fenical 1988, Hay \& Steinberg 1992). In addition to functioning as herbivore deterrents, algal secondary metabolites may also serve other roles such as allelochemicals, antifoulants (da Gama et al. 2003), antibiotics (Cronin 2001), or even perform multiple functions (Schmitt et al.
1995, Pereira et al. 2003). Secondary metabolite levels in marine macroalgae can be influenced by or correlated with a number of environmental factors including light intensity, desiccation, salinity and nutrient levels (e.g. Ilvessalo \& Tuomi 1989, Renaud et al. 1990, Yates \& Peckol 1993, Cronin \& Hay 1996ab, Peckol et al. 1996, Pavia et al. 1997, Pavia \& Brock 2000). These factors can exert stress on plant fitness. The 'environmental stress theory' suggests that an organism in a stressed state will be less able to acquire resources and will allocate these reduced resources to maintenance rather than defense production, assuming that the provision of defenses represents a metabolic cost (Cronin 2001).

Nutrient availability (especially of $\mathrm{N}$ and $\mathrm{P}$ ) tends to be a limiting factor for plant growth in marine systems (e.g. Larned 1998). Current allocation models, like the 'growth-differentiation balance hypothesis' or the 'carbon-nutrient balance hypothesis', consider resources responsible for allocation of defenses and predict phenotypic variation in the secondary defense metabolism of plants (Lerdau et al. 1997). They predict a negative correlation between growth and concentrations of Cbased secondary compounds like phlorotannins or terpenes (Haukioja et al. 1998) because of a trade-off between primary and secondary metabolic pathways (Herms \& Mattson 1992, Muzika 1993), which compete for limited resources within a plant (Glynn et al. 2003).

For this investigation, 9 different tropical algae were tested for induction of defense following direct grazing by amphipods. Furthermore, the effect of nutrients and different consumer activities on inducible defenses in a green alga was examined. This study attempted to determine whether the palatability levels of algae (i.e. the relative level of algae consumption by herbivores between treated and control algae) were affected by (1) different consumer activities or (2) interactive effects of consumers and nutrients, and (3) if found, which changes in palatability were caused by nonpolar chemical defenses?

\section{MATERIALS AND METHODS}

Sampling sites and organisms. Inducible defenses of 9 different species of algae (Table 1) were tested in 2 bio-assay induction experiments in the laboratory of the Department of Marine Biology of the Universidade Federal Fluminense (UFF) in Niterói (Rio de Janeiro state, Brazil), between January and May 2003.

Algae were collected by hand while SCUBA- or free-diving from the littoral zone of Rasa Beach and Forno Beach of the city Armação de Búzios $\left(22^{\circ} 45^{\prime}\right.$ to $22^{\circ} 49^{\prime} \mathrm{S}, 41^{\circ} 52^{\prime}$ to $41^{\circ} 57^{\prime} \mathrm{W}$ ), and from Itaipu Beach in Niterói $\left(23^{\circ} 54^{\prime} \mathrm{S}, 43^{\circ} 02^{\prime} \mathrm{W}\right)$; both places are located on the SE coast of Brazil. 
Table 1. Algae tested and characteristics of sampling sites. All sites are rocky shores at Búzios (Rio de Janeiro state, Brazil), except Itaipu, which is situated at Niterói (Rio de Janeiro state, Brazil)

\begin{tabular}{|c|c|c|c|}
\hline Alga & Location & Depth (m) & Zone \\
\hline \multicolumn{4}{|l|}{ Chlorophyta } \\
\hline Codium decorticatum (Woodw.) M. Howe & Itaipu & 2 & Subtidal \\
\hline \multicolumn{4}{|l|}{ Rhodophyta } \\
\hline Chondrophycus flagellifera (J. Agardh) Nam & Rasa & $1-2$ & Intertidal/subtidal \\
\hline Cryptonemia seminervis (C. Agardh) J. Agardh & Rasa & $1-2$ & Intertidal/subtidal \\
\hline Osmundaria obtusiloba (C. Agardh) R. E. Norris & Rasa & $1-2$ & Intertidal/subtidal \\
\hline Pterocladiella capillacea (S. G. Gmel.) Santel. \& Hommers. & Forno & 0.5 & Intertidal \\
\hline \multicolumn{4}{|l|}{ Phaeophyta } \\
\hline Dictyota menstrualis (Hoyt) Schnetter, Hörnig, \& Weber-Peukert & Rasa & $1-2$ & Intertidal/subtidal \\
\hline Lobophora variegata (J. V. Lamour.) Womersley ex E. C. Oliveira & Forno & 3 & Subtidal \\
\hline Sargassum vulgare C. Agardh & Rasa & $1-2$ & Intertidal/subtidal \\
\hline Stypopodium zonale (Lamour.) Papenf. & Forno & 3 & subtidal \\
\hline
\end{tabular}

In preliminary studies with 4 species of herbivores, the amphipod community dominated by Elasmopus brasiliensis was identified as the most suitable grazers for the experiments, primarily because they feed on all algae pieces with similar, continuous consumption rates. The number of amphipods per aquarium (30) was also determined in preliminary assays, so that amphipods could cause relatively small but detectable biomass loss. Amphipods were collected from Boa Viagem Beach (Niterói), where they occur in association with the common green alga Ulva fasciata and the bryozoans Bugula neritina and Zoobotryon verticillatum. They were immediately transferred to the laboratory and maintained in plastic trays with $U$. fasciata as a food source and shelter until needed.

Experimental set-up. In 2 closed water systems (ca. 9000 l), seawater was continuously aerated and filtered through a system comprised of sand, plankton mesh, activated carbon, and a protein skimmer. The water temperature was $18.5 \pm 1^{\circ} \mathrm{C}$, pH was $8.5 \pm 0.5(\mathrm{pH}-\mathrm{MV}$ TEMP-analyzer), and salinity was $36 \pm 1$ (Salinometer 5-10, No. 147, precision type Shibuya Optica).

Seawater was distributed by tubes (effective diameter $=0.4 \mathrm{~cm}$ ) to the experimental units $(\mathrm{EU})$, and water flux was regulated by flow controllers, exchanging the total water volume in EUs twice per day. The EUs comprised rectangular transparent plastic aquaria $(12 \times 18 \times 11 \mathrm{~cm}$, volume = $2 \mathrm{l})$ for treatments, and round transparent plastic aquaria (diameter $=14$, volume $=500 \mathrm{ml}$ ) for controls, each with an in- and outflow; treatment and control aquaria were always run as pairs. Preliminary studies had shown that the size and shape of aquaria did not affect plant growth as long as the water-flow rates were identical. In each rectangular aquarium, a transparent perforated $1 \mathrm{~mm}$ PVC plate was inserted to create 2 compartments (Fig. 1). All EU pairs were randomly arranged below large reservoirs that comprised part of both circulating water systems. Algae pieces were exposed to a 9:15 h light:dark cycle using daylight fluorescent lamps (40 $\mathrm{W}$, Agrolux). The lamps irradiated the target algae at a mean quantum flux density (Li-185 B, Li-Cor) of $26 \pm$ $18.1 \mu \mathrm{mol} \mathrm{m} \mathrm{m}^{-1}(\mathrm{n}=93)$. Seawater was recycled during the acclimatization and recovery phases (without consumers, see next subsection), but was used in a flow-through mode during the treatment phase (with consumers) to avoid possible contamination by waterborne chemical cues between EUs that could influence defense induction (Toth \& Pavia 2000).

Induction experiments. After collecting multiple individuals as a random sample from natural popula-

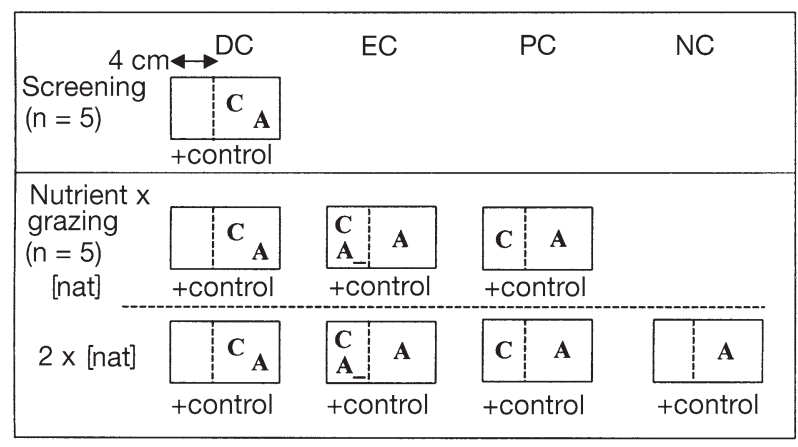

Fig. 1. Experimental units (EU) used in screening experiment and nutrient $\times$ grazing experiment. Treatment levels $(n=5)$ were DC (direct consumption), EC (nearby grazed conspecifics), PC (non-grazing consumers) and NC (no consumption; control + fertilizer). C: consumer (amphipods); A: test algae pieces; A_: alga pieces from same species; [nat]: natural nutrient concentration; $2 \times$ [nat]: 2 -fold natural nutrient concentration; vertical dashed line inside individual aquaria indicates transparent perforated PVC-plate; n: number of algae pieces per $\mathrm{EU}$; controls were always at natural nutrient concentrations and not exposed to consumers 
tions of each of the 9 algae species, and freeing them of epiphytes, 50 equally sized apical pieces of each species were cut and pooled. We randomly allocated 5 pieces from each species pool, with an average wet mass of $0.1005 \pm 0.0385 \mathrm{~g}$ (Cryptonemia seminervis), $0.1083 \pm 0.0289 \mathrm{~g}$ (Dictyota menstrualis), $0.1303 \pm$ $0.0605 \mathrm{~g}$ (Lobophora variegata), $0.2284 \pm 0.1019 \mathrm{~g}$ (Pterocladiella capillacea), $0.3502 \pm 0.1433 \mathrm{~g}$ (Osmundaria obtusiloba), $0.4046 \pm 0.1424 \mathrm{~g}$ (Stypopodium zonale), $0.5835 \pm 0.1539 \mathrm{~g}$ (Sargassum vulgare), $1.7474 \pm$ $0.7394 \mathrm{~g}$ (Chondrophycus flagellifera), and $1.7677 \pm$ $0.5773 \mathrm{~g}$ (Codium decorticatum) to $5 \mathrm{EU}$ pairs $(\mathrm{n}=5)$ for induction experiments. In addition, 10 pieces were deep-frozen immediately after collection and another 10 pieces were distributed pairwise into 5 rectangular EUs for comparison between natural defense level and level of defense after $14 \mathrm{~d}$.

The experiments consisted of 3 phases: acclimatization phase, treatment phase (defense induction by amphipod consumption), and recovery phase. During the acclimatization phase $(14 \mathrm{~d})$, pieces of algae were cultivated in the absence of amphipods to allow subsidence of unknown defense levels and acclimatization to experimental conditions. This phase allowed comparable initial conditions of pieces from different individual algae which might have had different grazing histories in the field prior to the induction treatment. During the treatment phase $(7 \mathrm{~d}), 30$ amphipods $(0.0441 \pm 0.0151 \mathrm{~g}$ blotted wet weight) were added to each rectangular EU as defense-inducers. During the recovery phase $(14 \mathrm{~d})$, the algae were allowed to recover in the absence of consumers in order to assess the relaxation of defense or retarded defense responses. The duration of the treatment phase was determined according to mean induction times given in the literature (e.g. Hammerstrom et al. 1998, Toth \& Pavia 2000).

We performed 2 experiments. In Expt 1, the screening experiment, 9 algae species (Table 1) were tested for induction of defense by direct amphipod grazing ( $\mathrm{n}=5$; Fig. 1). In Expt 2, the green alga Codium decorticatum was chosen to study the effects of herbivory and nutrients on the induction of defense in a full-cross $3 \times 2$ factorial experiment (nutrient $\times$ grazing experiment). This alga tended to display induced defenses after direct consumption and grew well under laboratory conditions during the screening experiment. We applied 3 consumption levels $(n=5)$ : (1) DC, direct consumption by amphipods; (2) EC, exposure to grazed algae (pieces of test algae were placed in the downstream compartment of a treatment EU receiving water from a compartment containing pieces of grazed algae); (3) PC, presence of consumers (test algae pieces were placed in the downstream compartment of a treatment EU receiving water from a compartment containing amphipods only). Nutrient treatments were conducted with: (1) a natural nutrient concentration in the seawater (nitrate concentration $18.1 \pm 0.2 \mu \mathrm{M}$ ); and (2) a 2 -fold natural nutrient concentration (100\% nitrate increase). In all, 6 treatment combinations were performed plus 1 treatment with the nutrient factor only (i.e. no consumption, NC in Fig. 1). The controls for each EU of the 7 treatments received natural seawater and were never exposed to consumers. Nutrient enrichment was achieved by addition of a nutrient stock solution, derived from slow-release NPK fertilizer beads (Planctacote pluss 4M, Aglukon). Besides nitrate, this fertilizer also provided additional potassium, phosphate, magnesium and other trace elements to the algae. At the beginning of the treatment phase, nutrients were added to the respective EUs and left in the seawater during the recovery phase.

Choice-feeding assays. Each phase (acclimatization, treatment, and recovery) was immediately followed by choice-feeding assays using entire pieces of live algae and artificial food containing non-polar extracts of the relevant alga. Differences in palatability between treated and control pieces of live algae can result from changes in chemical, morphological or nutritional algal traits (Hay et al. 1998) and do not allow the type of defense to be distinguished. Thus, incorporation of the algal extract into agar-based food was used to test for non-polar chemical deterrence by the algae. Only assays with artificial food containing non-polar extracts were performed in the nutrient $\times$ grazing experiment.

Feeding assays after the acclimatization phase compared the initial defense level of the alga (nonacclimatized; assumed to depend on an unknown in situ level of grazing prior to the experiments) with the level of defense after $14 \mathrm{~d}$ without any herbivory (acclimatized). Prior to these feeding assays, acclimated seaweed pieces were frozen for $2 \mathrm{~d}$ to achieve the same state as the already frozen, non-acclimated pieces at the beginning of the feeding experiment. In feeding assays after the treatment and recovery phases, feeding preference between control (unexposed to grazers) and treated (grazer-exposed and herbivore-damaged during the treatment phase) pieces was examined, using not just fresh growth but the entire algae piece from the respective phase. Therefore, if induction of anti-herbivore defenses occurred mostly in new growth, we may not have detected this effect, because of dilution through inclusion of older tissues. All choice-feeding assays were performed in round aquaria (diameter $=$ $14 \mathrm{~cm}$, volume $=500 \mathrm{ml})$, using 30 amphipods $(0.0441 \pm$ $0.0151 \mathrm{~g}$ blotted wet weight) per aquarium. Amphipods were not used in more than 1 assay and dead individuals were replaced. The assays lasted until either ca. $50 \%$ of 1 piece/pellet was eaten or $3 \mathrm{~d}$ elapsed, whichever occurred first. A control for autogenic chan- 
ges in live algae pieces was incorporated (pair of control and previously treated piece) to estimate change in biomass independent of consumption (Peterson \& Renaud 1989). Seawater from assay containers was exchanged daily during the assays.

Consumption rates $\left(\mathrm{mg} 3 \mathrm{~d}^{-1}\right.$ ) were calculated to assess relative differences in palatability between treated and control algae, using the difference in wet weight (resolution $0.1 \mathrm{mg}$ ) of live algae pieces before and after feeding-preference assays. Consumption rates were corrected for autogenic changes according to the formula of Cronin \& Hay (1996a). To minimize errors in measurement due to absorbed water, pieces were dried by blotting with absorbent paper prior to weighing. Consumption of diet containing non-polar extracts was calculated by counting the mesh squares without food.

Preparation of artificial food containing non-polar extracts. Artificial food was prepared according to Hay et al. (1994). We focused exclusively on the deterrent effects of lipid-soluble compounds extracted by dichloromethane (DCM) (Cetrulo \& Hay 2000). DCM extracts mainly lipid-soluble, relatively non-polar secondary metabolites, which are generally responsible for chemical defenses in algae (see Paul et al. 2001 and Steinberg et al. 2001 for reviews). Algae pieces for making food pellets were dried at room temperature (1 to $2 \mathrm{~d}$ ), then weighed and cut into small pieces prior to extraction ( 3 times) in $3.0 \mathrm{ml}$ of DCM with the help of ultrasound (1 min). The lipophilic extract was incorporated into a powder of the chemically undefended food alga Ulva fasciata that was equivalent to the dry weight of the original biomass of the target alga piece. The U. fasciata powder was then added to $6.0 \mathrm{ml}$ distilled water and mixed with a previously heated solution of $10.0 \mathrm{ml}$ distilled water and $0.4 \mathrm{~g}$ agar, after cooling to $\mathrm{ca} .60^{\circ} \mathrm{C}$. The mixture was then poured into a mold of PVC window screen $(10 \times 10$ squares, 1 square $=1 \mathrm{~mm}^{2}$ ), which provided both support for the agar pellet and an easy method of evaluating consumption by counting the squares consumed. Thin-layer chromatography (TLC) analysis of heated and non-heated extracts of all algae was performed to ensure that secondary metabolites in the extracts were not broken down by thermal degradation when added to the hot agar (Hay et al. 1987, Cetrulo \& Hay 2000).

Statistical analyses. Effect-ratios are the preferred response-variable for the analysis of consumption rates because, as a relative measurement, effect-ratios will adjust consumer-related differences in consumption rates due to (e.g.) size or starvation level of different amphipods. However, for live algae, we could not calculate effect-ratios because some algae pieces grew faster than the amphipods grazed them, resulting in negative consumption rates. For this reason we ana- lyzed the consumption data of live algae and artificial food in the screening experiment by different tests.

Consumption rates from live alga choice-feeding assays in the screening experiment were analyzed by a paired $t$-test for dependent samples (non-acclimatized versus acclimatized pieces; treated versus control pieces). We assessed whether artificial food from control algae was preferred over artificial food from treated algae, i.e. if an induction of alga defenses had occurred. This was done by testing whether an effect ratio of 1 (the null hypothesis) was higher and thus outside the $95 \% t$-distribution ( $\mathrm{df}=4$ ) of effect-ratios from our experiment (Underwood 1997, p. 62).

Prior to the analysis, homogeneity of variance was tested by Cochran's $C$-test. In the case of heterogeneous data, a log-transformation was applied and the data were rechecked for homogeneity. Heterogeneous data giving significant results with the paired $t$-test cannot be interpreted without error (Underwood 1997) and were thus analyzed by a Wilcoxon signed-ranks test.

In the nutrient $\times$ grazing experiment (interaction between defenses and nutrients) a paired $t$-test was conducted after the acclimatization phase (non-acclimatized versus acclimatized pieces). The homogeneity of the data was also tested by Cochran's $C$-test and followed the same steps as the screening experiment. Effect-ratios (number of squares consumed of artificial food containing non-polar extracts from the treated piece divided by the consumption of artificial food from the control piece) after the treatment and recovery phases were compared by 2-way ANOVA to analyze whether induction varied among herbivore exposure (fixed, 3 levels), among nutrient treatments (fixed, 2 levels) and whether nutrients and grazing type interacted to affect the preference for artificial food containing non-polar extracts from Codium decorticatum. In the advent of a significant result from the 2-way ANOVA, Tukey's post-hoc test was run to determine the position of the significant difference.

To assess whether the experiments had inadequate power to detect differences in consumption rates between control and treated plants, we used the software program 'Gpower V 2.0' (www.psycho.uniduesseldorf.de/aap/projects/gpower), to estimate the percent probability of detecting differences (Erdfelder et al. 1996).

\section{RESULTS}

\section{Screening experiment (Expt 1)}

Differences in the palatability of live algae and the diet containing non-polar extracts in response to herbivory were recorded. Acclimatized live pieces (left 


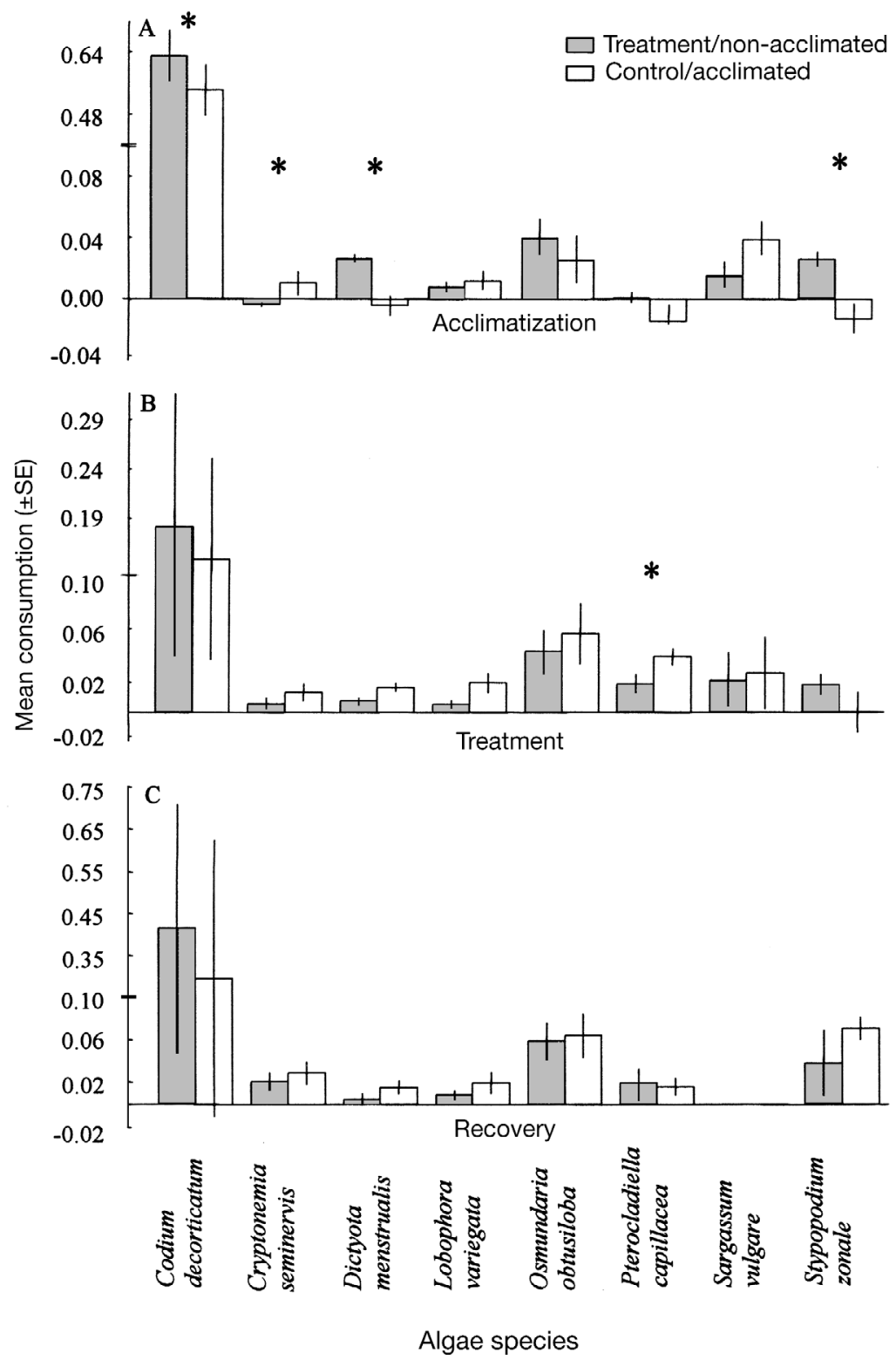

Fig. 2. Screening experiment (Expt 1). Mean ( \pm SE) grazing (g blotted wet mass) of Elasmopus brasiliensis-dominated amphipod community on live algae. Algae incubated with 30 grazer individuals in $3 \mathrm{~d}$ choice-feeding assays after (A) acclimatization, (B) treatment and (C) recovery phases, to assess relative differences in palatability between amphipod-exposed and non-exposed control algae. *Significant result of paired $t$-test comparing distribution of differences between control and treated algal pieces against null-hypothesis of no difference, note discontinuity in ordinates

ungrazed for $14 \mathrm{~d}$ following collection from the field) were consumed $32 \%$ more than non-acclimatized pieces for the red alga Cryptonemia seminervis (Wilcoxon signed-ranks test, $\left.Z_{4}=-2.02, \mathrm{p}=0.043\right)$, (Fig. 2A, Table 2). In contrast, non-acclimatized live pieces were preferred by 15 and $49 \%$ over acclimatized live pieces of the brown algae Dictyota men- strualis (paired $t$-test, $t_{4}=3.36, \mathrm{p}=0.028$ ) and Stypopodium zonale (paired $t$-test, $t_{4}=$ $3.73, \mathrm{p}=0.020)$, respectively, and by $14 \%$ for the green alga Codium decorticatum (paired $t$-test, $t_{4}=3.26, \mathrm{p}=0.031$ ); (Fig. 2A, Table 2). The probability of finding significant differences was $<80 \%$ for all species, except for $S$. zonale (82\%), C. decorticatum (85\%), and D. menstrualis (86\%). After the treatment phase (exposure to direct grazing by amphipods), the mean consumption of live control pieces of Pterocladiella capillacea was $50 \%$ higher than that for previously consumed pieces (paired $t$-test, $t_{4}=$ $-5.40, \mathrm{p}=0.006$ ); (Fig. 2B, Table 2). Likewise, the palatability of ungrazed live algae pieces was higher than that of previously grazed pieces in 3 brown algae and 2 red algae, whereas the reverse pattern was found for 1 brown and 1 green alga (Fig. 2B). Besides P. capillacea (99\% probability), feeding assays with other algae had a probability $<60 \%$ of finding significant differences. At the end of the recovery phase (14 d left ungrazed following the treatment phase), no significant results were detected in any of the feeding-preference experiments (Fig. 2C, Table 2). However, 3 brown algae and 2 red algae exhibited a nonsignificant trend for higher palatability levels of unconsumed compared to previously consumed live algae pieces. The opposite trend was observed for 1 species each of green, brown, and red alga (Fig. 2C). Test power was consistently $<50 \%$ probability at the end of the recovery phase. Sargassum vulgare could not be used for feeding assays after the recovery phase due to an infection by fungi. Likewise, feeding assays with live Chondrophycus flagellifera pieces were not performed because this species lost too many branches (probably as a result of herbivore activities) and thus could not provide reliable consumption data.

After the acclimatization phase, mean consumption of artificial food containing nonpolar extracts was not significantly different between acclimatized and non-acclimatized plants for any algae species (Fig. 3A, Table 2). Furthermore, there was no consistent trend. While acclimatized plants were preferred over non-acclimatized plants in 3 red and 2 brown algae, the opposite trend was displayed for 1 species each of green, red, and brown alga. Finally, identical consumption rates were detected between acclimatized and non-acclimatized 
pieces of the brown alga Dictyota menstrualis (Fig. 3A, Table 3). The probability of detecting significant differences in feeding-preference assays after the acclimatization phase was $>82 \%$ for all species except Sargassum vulgare $(74 \%)$ and Chondrophycus flagellifera $(28 \%)$. After the treatment phase, mean consumption rate of artificial food containing non-polar extracts of grazed and ungrazed plants was not significantly different for all 9 species (Fig. 3B, Table 2). As a trend, artificial food containing extracts of ungrazed $C$. flagellifera was more consumed than that from grazed conspecifics of this red alga (upper limit of $95 \%$-distribution = 1.094). Similarly, in 2 red, 1 green, and 3 brown algae, the palatability of ungrazed plants was higher than that of grazed conspecifics. The reverse pattern was observed for 1 brown and 1 red alga (Fig. 3B, Table 3). The probability of detecting significant differences was $>95 \%$ for feeding preference assays of all species, except Pterocladiella capillacea (25\%), Lobophora variegata $(28 \%)$, and Stypopodium zonale (53\%). After the recovery phase, a significant difference was found between consumption rates of artificial food containing extracts of the brown alga $L$. variegata (Fig. 3C, Table 2). Artificial food containing nonpolar extracts from ungrazed plants of $L$. variegata was preferred by $40 \%$ over artificial food from grazed conspecifics (upper limit of $95 \% t$-distribution $=0.923$ ). In addition, 2 red and 2 brown algae showed a nonsignificant trend for higher palatability of ungrazed
Table 2. Screening experiment (Expt 1). Statistical results of feeding assays with live algae (LA) and artificial food pellet containing non-polar algal extracts for acclimatization, treatment, and recovery phases of induction experiment. Data $(\mathrm{n}=5)$ analyzed with paired $t$-test or Wilcoxon signed-ranks test $\left({ }^{*}\right) ; \mathrm{n}=4$ in acclimatization phase of Dictyota menstrualis. ns: non-significant; nc: no contribution (Chondrophycus flagellifera lost branches and Sargassum vulgare was infected by fungi)

\begin{tabular}{|c|c|c|c|c|c|c|}
\hline \multirow[t]{2}{*}{ Alga } & \multicolumn{2}{|c|}{ Acclimatization } & \multicolumn{2}{|c|}{ Treatment } & \multicolumn{2}{|c|}{ Recovery } \\
\hline & $t$ & $\mathrm{p}$ & $t$ & $\mathrm{p}$ & $t$ & $\mathrm{p}$ \\
\hline \multicolumn{7}{|c|}{ Chondrophycus flagellifera } \\
\hline LA & $\mathrm{nc}$ & nc & $\mathrm{nc}$ & $\mathrm{nc}$ & $\mathrm{nc}$ & $\mathrm{nc}$ \\
\hline Pellet & -0.69 & ns & -3.32 & ns & -0.53 & ns \\
\hline \multicolumn{7}{|c|}{ Codium decorticatum } \\
\hline LA & 3.26 & $<0.05$ & 0.25 & ns & 0.72 & ns \\
\hline Pellet & 0.99 & ns & -2.49 & ns & 3.95 & ns \\
\hline \multicolumn{7}{|c|}{ Cryptonemia seminervis } \\
\hline LA & $-2.02^{*}$ & $<0.05$ & -1.16 & $\mathrm{~ns}$ & -0.48 & ns \\
\hline Pellet & 0.74 & ns & -1.22 & ns & 0.02 & ns \\
\hline \multicolumn{7}{|c|}{ Dictyota menstrualis } \\
\hline LA & 3.36 & $<0.05$ & -2.28 & $\mathrm{~ns}$ & -1.97 & ns \\
\hline Pellet & 0.08 & ns & 1.68 & ns & -2.52 & ns \\
\hline \multicolumn{7}{|c|}{ Lobophora variegata } \\
\hline LA & -0.51 & ns & -2.25 & ns & -0.99 & ns \\
\hline Pellet & 3.32 & ns & -0.13 & ns & -3.51 & $<0.05$ \\
\hline \multicolumn{7}{|c|}{ Osmundaria obtusiloba } \\
\hline LA & 0.57 & ns & -0.41 & ns & -0.18 & ns \\
\hline Pellet & -0.96 & ns & -0.55 & ns & 0.70 & ns \\
\hline \multicolumn{7}{|c|}{ Pterocladiella capillacea } \\
\hline LA & 2.08 & ns & -5.40 & $<0.05$ & 0.23 & ns \\
\hline Pellet & -2.68 & ns & 0.17 & ns & -0.24 & ns \\
\hline \multicolumn{7}{|c|}{ Sargassum vulgare } \\
\hline LA & -1.42 & $\mathrm{~ns}$ & -0.21 & $\mathrm{~ns}$ & $\mathrm{nc}$ & $\mathrm{nc}$ \\
\hline Pellet & -0.82 & ns & -2.58 & ns & 0.78 & ns \\
\hline \multicolumn{7}{|c|}{ Stypopodium zonale } \\
\hline LA & 3.73 & $<0.05$ & 1.03 & $\mathrm{~ns}$ & -1.36 & ns \\
\hline Pellet & -1.38 & ns & -0.07 & ns & -1.13 & ns \\
\hline
\end{tabular}

compared to grazed plants. The opposite pattern was displayed by 1 brown, 1 red and 1 green alga. Finally, amphipod consumption rates showed no trend for the red algae Cryptonemia seminervis (Fig. 3C, Table 3). The probability of detecting a significant difference in

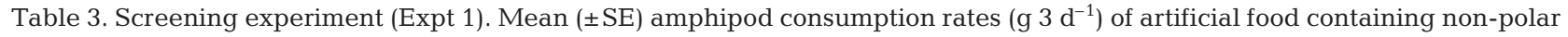
extracts for each alga during $3 \mathrm{~d}$ choice-feeding assays (see 'Materials and methods' for details) after each phase of induction experiment. $n=5\left({ }^{*} n=4\right)$, non-a: non-acclimatized; a: acclimatized; t: grazed; c: ungrazed. See Table 2 for full species names

\begin{tabular}{|c|c|c|c|c|c|c|}
\hline \multirow[t]{2}{*}{ Alga } & \multicolumn{2}{|c|}{ Acclimatization } & \multicolumn{2}{|c|}{ Treatment } & \multicolumn{2}{|c|}{ Recovery } \\
\hline & non-a & $\mathrm{a}$ & $\mathrm{t}$ & C & $\mathrm{t}$ & $\mathrm{C}$ \\
\hline C. flagellifera & $45.6( \pm 11.7)$ & $58.2( \pm 14.9)$ & $70.8( \pm 12.3)$ & $78.8( \pm 10.6)$ & $48.6( \pm 3.5)$ & $52.8( \pm 7.0)$ \\
\hline C. decorticatum & $45.6( \pm 7.0)$ & $37.2( \pm 4.9)$ & $48.4( \pm 6.0)$ & $62.6( \pm 4.6)$ & $68.4( \pm 5.7)$ & $51.8( \pm 5.1)$ \\
\hline C. seminervis & $54.2( \pm 12.5)$ & $42.2( \pm 4.3)$ & $69.6( \pm 4.8)$ & $80.4( \pm 5.9)$ & $55.0( \pm 6.5)$ & $54.8( \pm 9.6)$ \\
\hline D. menstrualis & $46.5( \pm 4.4)^{*}$ & $46.0( \pm 3.6)^{*}$ & $70.2( \pm 9.4)$ & $56.6( \pm 15.2)$ & $37.0( \pm 5.7)$ & $50.8( \pm 1.9)$ \\
\hline L. variegata & $53.8( \pm 3.1)$ & $32.6( \pm 4.9)$ & $49.6( \pm 12.1)$ & $53.0( \pm 17.9)$ & $47.4( \pm 9.6)$ & $66.4( \pm 8.1)$ \\
\hline O. obtusiloba & $40.4( \pm 6.0)$ & $47.8( \pm 4.1)$ & $54.2( \pm 7.6)$ & $61.8( \pm 7.2)$ & $48.0( \pm 5.9)$ & $37.6( \pm 9.6)$ \\
\hline P. capillacea & $41.4( \pm 4.8)$ & $51.0( \pm 3.1)$ & $56.0( \pm 16.7)$ & $52.2( \pm 15.1)$ & $53.4( \pm 8.9)$ & $55.6( \pm 7.5)$ \\
\hline S. vulgare & $38.4( \pm 8.3)$ & $49.8( \pm 8.8)$ & $46.0( \pm 5.7)$ & $60.2( \pm 4.1)$ & $61.6( \pm 10.1)$ & $48.0( \pm 10.5)$ \\
\hline S. zonale & $33.4( \pm 6.4)$ & $47.2( \pm 5.6)$ & $44.6( \pm 4.9)$ & $45.6( \pm 10.7)$ & $46.2( \pm 8.0)$ & $60.4( \pm 9.9)$ \\
\hline
\end{tabular}



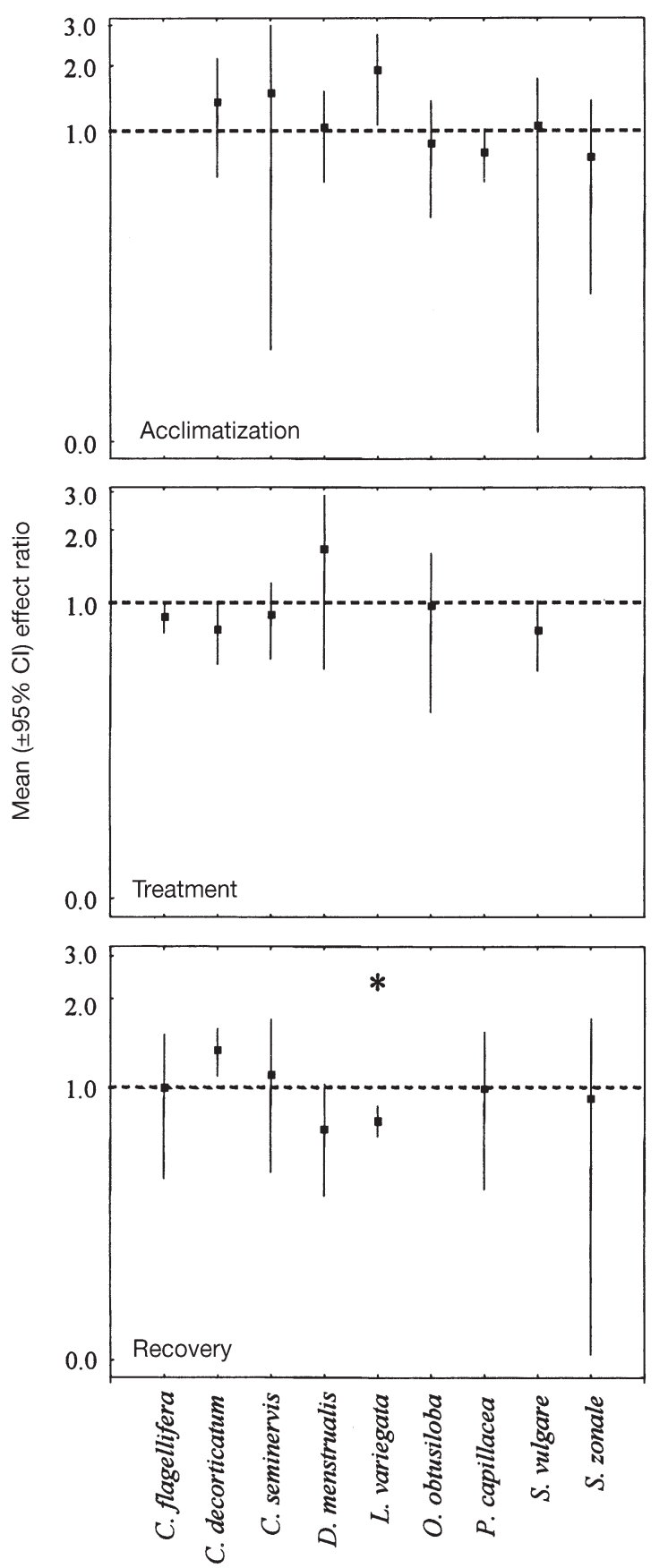

Fig. 3. Screening experiment (Expt 1). Effect-ratios (amphipod consumption rate of treated plants/consumption rate on control plants) derived from choice-feeding assays with artificial food containing non-polar extracts for each species of alga and phase of induction experiment. Horizontal dashed lines indicate effect-ratio of 1 predicted by null hypothesis. Significant defense responses $(*)$ recorded where the mean effect-ratio $<1$ and $95 \%$ confidence intervals (CI) do not cross dashed line. Note logarithmic scaling of ordinates to maximize optical resolution of effect-ratios around the null hypothesis. Effect-ratios of algae with CI limit of $<0$ never showed significant defense response and were omitted to maintain logarithmic scaling. Conditions of choice-feeding assays and full specific names as in Fig. 2 feeding preference assays after the recovery phase was $>81 \%$ for all species except Osmundaria obtusiloba $(25 \%)$ and $S$. vulgare (35\%).

\section{Interaction between defenses and nutrients (Expt 2)}

Amphipods significantly preferred artificial food containing non-polar extracts from acclimatized Codium decorticatum pieces over artificial food from non-acclimatized pieces (Table 4). Mean consumption of acclimatized artificial food increased by $91 \%$ (paired $t$-test, $t_{4}=-7.25, \mathrm{p}=0.002$ ). After the treatment and recovery phases, differences in consumption activities, nutrients, or a combination of both did not affect algal palatability relative to controls (Fig. 4, Table 5).

A 2-way ANOVA showed no effect of consumption, nutrients or both factors together after the treatment phase (Table 4). At the end of the recovery phase, the effects of the direct consumption treatment were significantly greater than those of the other consumer treatments (Fig. 4, Table 5), indicating a relatively stronger increase in palatability of algae pieces from the direct grazing treatment compared to controls than for indirect and consumer-presence treatments. During the recovery phase, the presence of nutrients resulted in decreased palatability of Codium decorticatum by an average of $18 \%$ (2-way ANOVA, $F=6.90, \mathrm{p}=0.015)$, compared to unfertilized treatments. A significant consumption $\times$ nutrient interaction indicated that consumer effects depended on nutrient levels (2-way ANOVA, $F=3.93$, $\mathrm{p}=0.033$ ). During the nutrient enrichment treatment, growth of $C$. decorticatum decreased by $27 \%$ ( $t$-test, $\left.t_{9}=2.461, \mathrm{p}=0.024\right)$ compared to unfertilized controls.

Table 4. Main and interactive effects between grazing and nutrient treatments. Results from choice-feeding assays (Expt 2) of artificial food containing non-polar extracts of Codium decorticatum after acclimatization, treatment, and recovery phases $(\mathrm{n}=5) . t$ : test statistic (paired $t$-test); $F$ : test statistic (2-way ANOVA); C: consumption; N: nutrients; $\mathrm{C} \times \mathrm{N}$ : interactive effects of $\mathrm{C}$ and $\mathrm{N}_{i}$ ns: non-significant

\begin{tabular}{|lcc|}
\hline \multicolumn{1}{|c|}{$t$} & $\mathrm{p}$ \\
\hline Acclimatization phase & & \\
Effect & -6.68 & $<0.05$ \\
& $F$ & $\mathrm{p}$ \\
\hline Treatment phase & & \\
$\mathrm{C}$ & 0.54 & $\mathrm{~ns}$ \\
$\mathrm{~N}$ & 1.86 & $\mathrm{~ns}$ \\
$\mathrm{C} \times \mathrm{N}$ & 0.11 & $\mathrm{~ns}$ \\
Recovery phase & & $\mathrm{ns}$ \\
$\mathrm{C}$ & 2.25 & $<0.05$ \\
$\mathrm{~N}$ & 6.90 & $<0.05$ \\
$\mathrm{C} \times \mathrm{N}$ & 3.93 & \\
\hline
\end{tabular}




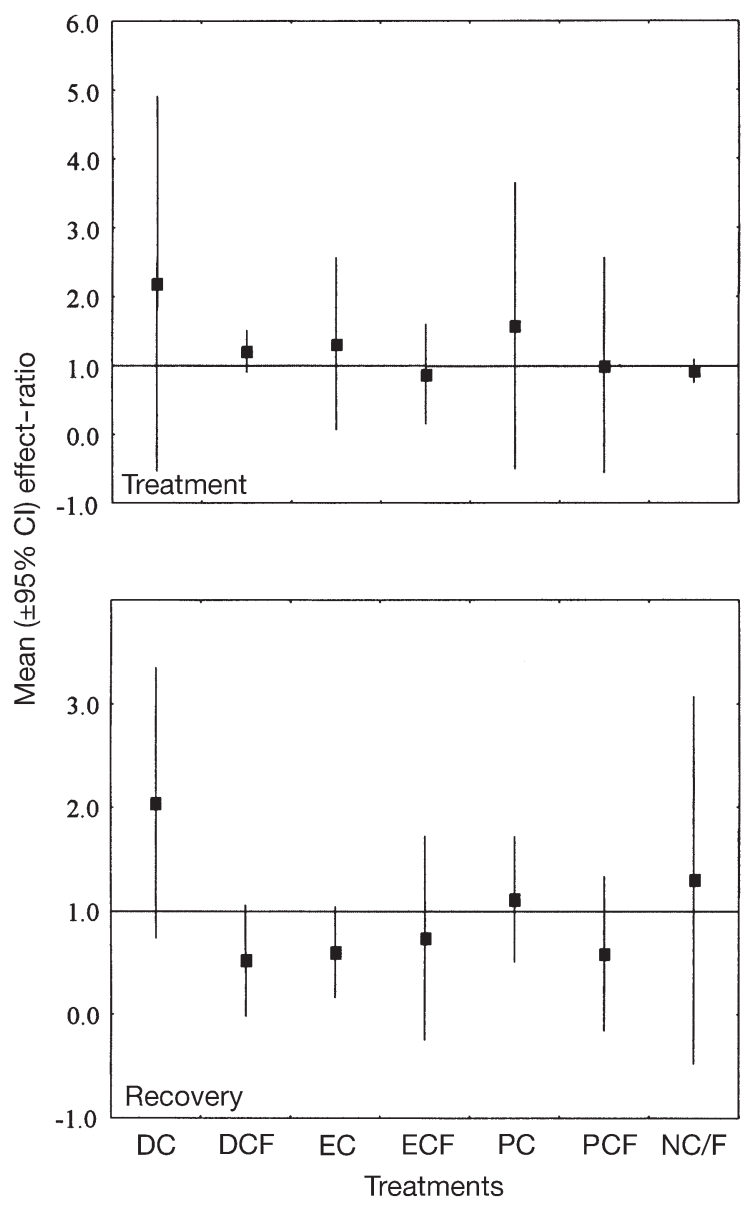

Fig. 4. Nutrient $\times$ grazing experiment (Expt 2). Effect-ratio (amphipod consumption rate of treated artificial food/ consumption rate of control artificial food) for Codium decorticatum after treatment and recovery phase. Horizontal continuous line indicates the effect-ratio of null hypothesis. Significant defense responses recorded where mean effect-ratio $<1$ and $95 \%$ confidence intervals (CI) do not cross continuous line. DC: direct consumption; DCF: DC + fertilizer; EC: nearby grazed conspecifics; ECF: EC + fertilizer; PC: nongrazing consumers; PCF: PC + fertilizer; NC/F: control + fertilizer. Conditions of choice-feeding assays as in Fig. 2

Table 5. Nutrient $\times$ grazing experiment $($ Expt 2$)$. Mean $( \pm$ SE) amphipod consumption rates $\left(1 \mathrm{~mm}^{2}\right.$ squares $\left.3 \mathrm{~d}^{-1}\right)$ of artificial food containing non-polar extracts of green alga Codium decorticatum for all treatments including 'nutrients' and 'consumers' as main effects during feeding assays after treatment and recovery phases of induction experiment. $\mathrm{n}=$ sample size

\begin{tabular}{|lrll|}
\hline Experiment & $\mathrm{n}$ & Treatment & Recovery \\
\hline Direct consumption & 5 & $51.0( \pm 14.3)$ & $51.8( \pm 14.7)$ \\
Direct consumption + fertilizer & 5 & $72.6( \pm 7.5)$ & $23.4( \pm 5.8)$ \\
Nearby grazed conspecifics & 5 & $10.0( \pm 2.3)$ & $43.0( \pm 16.5)$ \\
Nearby grazed conspecifics + fertilizer & 5 & $55.2( \pm 14.4)$ & $41.8( \pm 12.2)$ \\
Non-grazing consumers & 5 & $46.0( \pm 16.2)$ & $59.6( \pm 7.3)$ \\
Non-grazing consumers + fertilizer & 5 & $32.6( \pm 9.7)$ & $34.6( \pm 15.1)$ \\
Control & 35 & $50.8( \pm 5.4)$ & $59.3( \pm 4.6)$ \\
Control + fertilizer & 5 & $82.4( \pm 8.1)$ & $43.8( \pm 8.0)$ \\
& & & \\
\hline
\end{tabular}

\section{DISCUSSION}

In marine systems, inducible defenses are only known to exist in a few species of macroalgae. This study is the first to describe grazing-induced defenses among Brazilian tropical algae. Out of 4 red algae, 1 (Pterocladiella capillacea) exhibited inducible defenses following direct consumption by amphipods. Surprisingly, only 1 of 4 brown algae studied (Lobophora variegata) displayed induced (delayed) defenses: the green alga Codium decorticatum did not respond significantly to direct grazing or water-borne signals of nearby grazers and grazed conspecifics by any detectable change in palatability, whereas nutrient enrichment seemed to trigger a change in palatability after a lag phase of $3 \mathrm{wk}$.

\section{Screening experiment (Expt 1)}

Most differences in palatability were found after the acclimatization phase between acclimatized and nonacclimatized live algae, probably indicating that transfer to laboratory conditions requires some acclimatization time for the macroalgal species. Live algae either increased or decreased in palatability, probably due to algae-specific responses to an altered light or hydrodynamic regime under laboratory conditions, or the absence of consumers. Indeed, it is not clear whether altered abiotic conditions or changes in the defense status, or both, were responsible for the observed changes in algal palatability after this phase. However, we demonstrated the need for such acclimatization phase to achieve comparable initial conditions for detecting grazer-mediated rather than laboratorymediated changes in algal palatability. However, changes in palatability of live algae were not confirmed with artificial food containing non-polar extracts, suggesting that either the nutritional value (e.g. proteins, sugars) of the algae had changed under the cultivation conditions or lipid-soluble compounds extracted by DCM were not responsible for affecting amphipod preference.

After the treatment phase, 8 of 9 consumer-exposed algae were less palatable than untreated conspecifics. Pavia \& Toth (2000) reported that, under natural conditions, a response to grazing by mesoherbivores within 2 to 4 wk could be considered a short-term response, since this type of small, relatively immobile mesograzer can feed on the same alga for long periods and would thus experience any changes 
they induce. We have demonstrated that grazing by amphipod mesograzers can trigger resistance in the red alga Pterocladiella capillacea within 1 wk under laboratory conditions. Live pieces of $P$. capillacea following amphipod grazing were less preferred than control pieces, but this was not the case for artificial food containing non-polar algae extracts. The higher palatability of live control over treated plants was not likely to have been simply due to grazers having eaten all the more palatable tissues in control plants, because amphipod consumption never exceeded $15 \%$ of algal wet mass during the induction experiment, suggesting that there was still enough palatable tissue available for amphipods in treated algae pieces during the feeding assay. Therefore, this result indicates the presence of a deterrent polar substance, which could not be extracted by DCM. Furthermore, almost significant results with artificial food containing non-polar extracts of the red algae Chondrophycus flagellifera suggest the presence of chemical defenses. Many species of tropical red algae, including members of the genus Chondrophycus, are known to produce a diverse array of halogenated secondary metabolites (Paul et al. 1987, Faulkner 2001, Garson 2001), and some have been shown to act constitutively as feeding deterrents in addition to other ecological roles (Hay et al. 1987, da Gama et al. 2003, Pereira et al. 2003); yet this study is the first to report on the ability of red algae to induce defenses. Our data do not, however, rigorously exclude the possibility that induction of defense in P. capillacea could be attributed to a morphological trait. Evidence for a plasticity of morphological traits in $P$. capillacea comes from the study by Scrosati (2002), who observed stress-mediated development of branches in this species. Similarly, Van Alstyne (1989) detected grazer-induced growth of adventitious branches in the brown alga Fucus distichus that were less palatable to snails than normal merestematic tissue of apices. The results of both studies suggest that additional thallus growth could be one indicator of induced morphological defense responses. However, this response was not observed in our experiments, increasing the probability that induced defenses in P. capillacea were due to a chemical mechanism.

Among the Phaeophyta screened, Lobophora variegata showed an induction of anti-herbivore defenses, a result that has not previously been published. In contrast to the experiments of Cronin \& Hay (1996c), Dictyota menstrualis did not exhibit inducible defenses after exposure to amphipods. It has been shown that Brazilian D. menstrualis deters feeding by the amphipod Parhyale hawaiensis, suggesting that this alga is constitutively defended (Pereira et al. 2000a,b). Pereira et al. $(2000 a, b)$ reported that its defensive response was quite strong (14 \pm 9 amphipods died per day) dur- ing our feeding assays. This confirms the high mortality rates of grazers which might explain the high rate of mortality and foulers on this alga (e.g. high mortality of bryozoan larvae exposed to $D$. menstrualis extracts occurred in the study of Schmitt et al. 1995). The difference in the ability of grazers to induce defenses in $D$. menstrualis between the present study and that of Cronin \& Hay (1996c) indicates that induced defenses may be a grazer-specific response of algae, as has previously been assumed (Hay et al. 1987, 1988, Paul et al. 1987, Pereira et al. 2000a, Amsler 2001, Van Alstyne et al. 2001). Thus, our results may not be useful for predicting how the algae tested will respond to grazing by other herbivores of the study system or of other systems. Although Stypopodium zonale did not display defense induction by amphipod grazing, we did observe a strong repulsive effect, since $27 \pm 3$ amphipods died within a $48 \mathrm{~h}$ treatment period during feeding assays. This corroborates the finding of Soares et al. (2003) that $S$. zonale possesses constitutive chemical defenses. Soares et al. (2003) found that natural concentrations of $S$. zonale secondary metabolites at Forno Beach deterred feeding by the sea urchin Lytechinus variegatus and the crab Pachygrapsus transversus.

The palatability levels of treated and control plants of Pterocladiella capillacea were no longer significantly different, 2 wk after consumption ceased, indicating an as yet unreported regulatory capacity of algae to mobilize defenses when consumed and to reduce defenses when grazing pressure ceases. Furthermore, we observed retarded induction of chemical defense in artificial food made from non-polar extracts, but not in live pieces of Lobophora variegata. This suggests that repulsive effects of the non-polar extracts were overridden by counteracting effects of non-extracted chemicals, making (e.g.) live plants more nutritive.

\section{Interaction between defenses and nutrients (Expt 2)}

The effects of nutrient availability and consumption on defense induction were examined in the green alga Codium decorticatum because of its tendency to show induced chemical defenses in the screening experiment.

In contrast to the screening experiment (i.e. Expt 1), in Expt 2 the diet containing non-polar extracts from acclimatized pieces was more palatable than that from non-acclimatized pieces. The Codium decorticatum pieces used in Expt 2 were collected from the same location as those for the screening experiment, but at different times. Thus, contrasting patterns in the palatability of $C$. decorticatum after acclimatization suggest a change in its chemistry within a time span of 7 wk. Likewise, Van Alstyne et al. (2001) reported 
strong changes in the chemical composition of macroalgae, over short time spans ranging from days to months, due to dynamics in herbivore populations and environmental factors. As in Expt 1, an acclimatization phase seemed to be necessary in Expt 2 to allow acclimatization of $C$. decorticatum to laboratory conditions.

Neither direct consumption nor water-borne cues of consuming and non-consuming amphipods induced resistance in Codium decorticatum. Defense induction in a green alga, triggered by the reception of waterborne cues from nearby grazed conspecifics, was only detected in Ulva reticulata (J. Ceh pers. comm.). Furthermore, the brown algae Ascophyllum nodosum (Toth \& Pavia 2000), Fucus serratus (Rohde 2003) and Glossophora kunthii (E. Macaya pers. comm.) decreased in palatability after receiving water-borne signals from algae and/or herbivores. In natural habitats, C. decorticatum individuals do not grow in dense stands (Teixeira et al. 1984, K. Weidner pers. obs.), reducing the chances of receiving water-borne cues from neighboring grazed plants. Thus, the life-history traits of C. decorticatum make water-borne cues less likely to be an advantageous selective trait for this alga.

Unexpectedly, direct consumption by amphipods showed a trend to enhance the palatability of Codium decorticatum (Table 5). This contrasts with the induced defense theory, but corroborates the results of the screening experiment and of a parallel study on snailexposed Codium platylobium from South Africa (E. Díaz pers. comm.). Consumer-mediated damage of algal tissues may have induced the production of compounds that stimulated feeding (Cetrulo \& Hay 2000), or may have facilitated access of amphipods beyond the physical defensive barriers of the alga. Likewise, consumers could have adapted to or possibly even have been stimulated by plant defense compounds, as has been described for other mesograzers (e.g. Hay et al. 1987).

Enhanced nutrient concentrations did not affect the palatability levels of Codium decorticatum, nor was there any interactive effect of nutrient addition with grazing on defense induction. The reduced growth of fertilized plants compared to unfertilized plants could suggest that $C$. decorticatum fragments were stressed by higher nutrient levels. Most studies have found that nutrient enrichment results in increased growth rates (e.g. Creed et al. 1997) or has no effect (e.g. Erftemeijer et al. 1994), and yet Schaffelke \& Klumpp (1998) reported reduced growth rates in Sargassum baccularia due to fertilizer treatment above a growth-stimulating concentration range. Likewise, Van Alstyne \& Pelletreau (2000) reported a negative effect of phosphorus and iron enrichment on the growth of Fucus gardneri embryos. The fertilizer beads that we used for enrichment provided a high proportion of ammonium $(7.7 \%$ out of $14 \%$ total $N$ ) that could have exceeded $50 \mu \mathrm{M}$, above which level toxic effects on algae have been observed (Waite \& Mitchell 1972), and this may have reduced growth. Moreover, ambient levels of nitrate may have been very high $(18.1 \mu \mathrm{M})$, and thus probably well in excess of algal requirements. In regard to our observation that palatability was not affected by nutrient addition, the 'environmental stress theory' may be applicable, whereby under stress, all resources will be allocated to maintenance rather than defense.

Allocation models, such as the 'growth-differentiation balance hypothesis' or the 'carbon-nitrogen balance hypothesis', assume a negative correlation between the concentration of C-based secondary compounds (e.g. terpenes) and plant growth rates because both processes compete for limited resources within a plant (Haukioja et al. 1998, Glynn et al. 2003). Therefore, increased growth rates and a concurrent increase in the palatability of fertilized Codium decorticatum pieces to amphipods should have occurred due to decreased defenses. However, this pattern was not found, rather, the opposite was observed after 3 wk fertilization: the fertilizer in combination with grazing seemed to improve the alga's defense capacity. This may have been due to the chemical composition of green algae. Most deterrent compounds isolated from green algae are terpenes (e.g. Paul \& Van Alstyne 1988, Cronin 2001), but evidence from many studies shows that the 'growth-differentiation balance hypothesis' and the 'carbon-nitrogen balance hypothesis' predict the responses of phlorotannins (Ilvessalo \& Tuomi 1989, Peckol \& Yates 1997) but not of terpenes (Cronin \& Hay 1996c, Puglisi \& Paul 1997). This discrepancy due to nutrient availability could be explained by the 'biosynthesispathway hypothesis', assuming that trade-offs with growth are more likely for phenolic than for terpene biosynthesis (Muzika 1993, Haukioja et al. 1998), since there is direct competition between protein and polyphenol biosynthesis for an equal precursor whereas precursors for terpene biosynthesis are more generalized and use many pathways (Muzika 1993). However, interpretation of our data is not possible with current hypotheses.

It seems either that Codium decorticatum does not possess deterrent secondary metabolites against Elasmopus brasiliensis or that laboratory conditions and nutrient enrichment stress the alga to such an extent that it is unable to respond with defenses. Our results support the suggestion of Peckol et al. (1996) that production of defenses is likely to be controlled by a complex interaction of environmental, developmental and defense-related factors.

A growing number of studies conclude that defense induction among macroalgae is not a simple, straightforward process, but rather a result of complex interac- 
tions of a number of biotic and extrinsic abiotic factors (Pavia \& Brock 2000, Van Alstyne \& Pelletreau 2000). By manipulating these factors under controlled conditions, and screening defense induction among several species of algae, we can expect to cast some light upon the mechanisms by which macroalgae regulate herbivore consumption and thus control an important part of the food web in marine systems.

Acknowledgements. We gratefully acknowledge funding by Stiftung Mercator GmbH. The authors thank J. H. S. Miyamoto for maintaining the experimental set-up, as well as B. L. Antunes, A. C. Pessanha and other helpers from the UFF for patient assistance in the field and laboratory. Furthermore we would like to thank R. Villaça and Y. Yoneshigue-Valentin for identification of algae, A. Güth for identification of the amphipods, and S. O. Lourenço for the nutrient analysis. We are grateful to G. McFall and H. Heilmeier for reviewing the manuscript. The comments from anonymous reviewers greatly improved an earlier version of the manuscript. This work was performed as part of an international student training and scientific research project, GAME (Global Approach by Modular Experiments), and communications with other GAME students were helpful when writing this paper.

\section{LITERATURE CITED}

Agrawal AA, Karban R (1999) Why induced defenses may be favored over constitutive strategies in plants. In: Tollrian $\mathrm{R}$, Harvell C (eds) The ecology and evolution of inducible defenses, Vol 1. Princeton University Press, Princeton, NJ, p 45-61

Amsler CD (2001) Induced defenses in macroalgae: the herbivore makes the difference. J Phycol 37:353-356

Cetrulo GL, Hay ME (2000) Activated chemical defenses in tropical versus temperate seaweeds. Mar Ecol Prog Ser 207:243-253

Creed JC, Norton TA, Kain JM (1997) Intraspecific competition in Fucus serratus germlings: the interaction of light, nutrients and density. J Exp Mar Biol Ecol 212:211-223

Cronin G (2001) Resource allocation in seaweeds and marine invertebrates: chemical defense patterns in relation to defense theories. In: McClintock JB, Baker BJ (eds) Marine chemical ecology. CRC Press, Boca Raton, p 325-353

Cronin G, Hay ME (1996a) Effects of light and nutrient availability on the growth, secondary chemistry, and resistance to herbivory of two brown seaweeds. Oikos 77:93-106

Cronin G, Hay ME (1996b) Susceptibility to herbivores depends on recent history of both the plant and animal. Ecology 77:1531-1543

Cronin G, Hay ME (1996c) Induction of seaweed chemical defenses by amphipod grazing. Ecology 77:2287-2301

da Gama BAP, Pereira RC, Soares AR, Teixeira VL, Yoneshigue-Valentin Y (2003) Is the mussel test a good indicator of antifouling activity? A comparison between laboratory and field assays. Biofouling 19:161-169

Duffy JE, Hay ME (1991) Food and shelter as determinants of food choice by an herbivorous marine amphipod. Ecology 72:1286-1298

Duffy JE, Hay ME (2000) Strong impacts of grazing amphipods on the organization of a benthic community. Ecol Monogr 70:237-263
Erdfelder E, Faul F, Buchner A (1996) GPOWER: a general power analysis program. Behav Res Meth Instrum Comput 28:1-11

Erftemeijer PLA, Stapel J, Smekens MJE, Drossaert WME (1994) The limited effect of in situ phosphorus and nitrogen additions to seagrass beds on carbonate and terrigenous sediments in South Sulawesi, Indonesia. J Exp Mar Biol Ecol 182:123-140

Faulkner DJ (2001) Marine natural products. Nat Prod Rep 18: $1-49$

Garson MJ (2001) Ecological perspectives on marine natural product biosynthesis. In: McClintock J, Baker B (eds) Marine chemical ecology. CRC Press, Boca Raton, p 71-114

Glynn C, Herms DA, Egawa M, Hansen R, Mattson WJ (2003) Effects of nutrient availability on biomass allocation as well as constitutive and rapid induced herbivore resistance in poplar. Oikos 101:385-397

Hammerstrom K, Dethier MN, Duggins DO (1998) Rapid phlorotannin induction and relaxation in five Washington kelps. Mar Ecol Prog Ser 165:293-305

Haukioja E, Ossipov V, Koricheva J, Honkanen T, Larsson S, Lempa K (1998) Biosynthetic origin of carbon-based secondary compounds: cause of variable responses of woody plants to fertilization? Chemoecology 8:133-139

Hay ME (1997) The ecology and evolution of seaweedherbivore interactions on coral reefs. Coral Reefs 16:67-76

Hay ME, Fenical W (1988) Marine plant-herbivore interactions: the ecology of chemical defense. Annu Rev Ecol Syst 19:111-145

Hay ME, Steinberg PD (1992) The chemical ecology of plantherbivore interactions in marine versus terrestrial communities. In: Rosenthal G, Berenbaum M (eds) Herbivores: their interactions with secondary plant metabolites, Vol 2, Harcourt Brace Jovanovich, San Diego, p 371-413

Hay ME, Duffy JE, Pfister CA, Fenical W (1987) Chemical defense against different marine herbivores: are amphipods insect equivalents? Ecology 68:1567-1580

Hay ME, Kappel QE, Fenical W (1994) Synergisms in plant defenses against herbivores: interactions of chemistry, calcification, and plant quality. Ecology 75:1714-1726

Hay ME, Stachowicz JJ, Cruz-Rivera E, Bullard S, Deal MS, Lindquist N (1998) Bioassays with marine and freshwater macroorganisms. In: Haynes K, Millar J (eds) Methods in chemical ecology. Bioassays methods, Vol 2. Chapman \& Hall, London, p 39-141

Herms DA, Mattson WJ (1992) The dilemma of plants: to grow or defend. Q Rev Biol 67:283-335

Ilvessalo H, Tuomi J (1989) Nutrient availability and accumulation of phenolic compounds in the brown alga Fucus vesiculosus. Mar Biol 101:115-119

Larned ST (1998) Nitrogen- versus phosphorus-limited growth and sources of nutrients for coral reef macroalgae. Mar Biol 132:409-421

Lerdau M, Litvak M, Palmer P, Monson R (1997) Controls over monoterpene emissions from boreal forest conifers. Tree Physiol 17:563-569

Muzika RM (1993) Terpenes and phenolics in response to nitrogen fertilization: a test of the carbon/nutrient balance hypothesis. Chemoecology 4:3-7

Paul VJ, Van Alstyne KL (1988) Chemical defense and chemical variation in some tropical Pacific species of Halimeda (Halimedaceae; Chlorophyta). Coral Reefs 6:263-269

Paul VJ, Van Alstyne KL (1992) Activation of chemical defenses in the tropical green algae Halimeda spp. J Exp Mar Biol Ecol 160:191-203

Paul VJ, Hay ME, Duffy JE, Fenical W, Gustafson K (1987) Chemical defense in the seaweed Ochtodes secundiramea 
(Montagne) Howe (Rhodophyta): effects of its monoterpenoid components upon diverse coral-reef herbivores. J Exp Mar Biol Ecol 114:249-260

Paul VJ, Cruz-Rivera E, Thacker RW (2001) Chemical mediation of macroalgal-herbivore interactions: ecological and evolutionary perspectives. In: McClintock JB, Baker BJ (eds) Marine chemical ecology. CRC Press, Boca Raton, p 227-265

Pavia H, Brock E (2000) Extrinsic factors influencing phlorotannin production in the brown alga Ascophyllum nodosum. Mar Ecol Prog Ser 193:285-294

Pavia H, Toth GB (2000) Inducible chemical resistance to herbivory in the brown seaweed Ascophyllum nodosum. Ecology 81:3212-3225

Pavia H, Cervin G, Lindgren A, Aberg P (1997) Effects of UV$B$ radiation and simulated herbivory on phlorotannins in the brown alga Ascophyllum nodosum. Mar Ecol Prog Ser 157:139-146

Peckol P, Yates JL (1997) Inducible phlorotannin levels in brown algae from backreef sites. Proc 8th Int Coral Reef Symp 2:1259-1262

Peckol P, Krane JM, Yates JL (1996) Interactive effects of inducible defense and resource availability on phlorotannins in the North Atlantic brown alga Fucus vesiculosus. Mar Ecol Prog Ser 138:209-217

Pereira RC, Cavalcanti DN, Teixeira VL (2000a) Effects of secondary metabolites from the tropical Brazilian brown alga Dictyota menstrualis on the amphipod Parhyale hawaiensis. Mar Ecol Prog Ser 205:95-100

Pereira RC, Donato R, Teixeira VL, Cavalcanti DN (2000b) Chemotaxis and chemical defenses in seaweed susceptibility to herbivory. Rev Bras Biol 60:405-414

Pereira RC, da Gama BAP, Teixeira VL, Yoneshigue-Valentin Y (2003) Ecological roles of natural products from the Brazilian red seaweed Laurencia obtusa. Braz J Biol 63: 665-672

Peterson CH, Renaud PE (1989) Analysis of feeding preference experiments. Oecologia 80:82-86

Puglisi MP, Paul VJ (1997) Intraspecific variation in the red alga Portieria hornemannii: monoterpene concentrations are not influenced by nitrogen or phosphorus enrichment. Mar Biol 128:161-170

Renaud PE, Hay ME, Schmitt TM (1990) Interactions of plant stress and herbivory: intraspecific variation in the susceptibility of a palatable versus an unpalatable seaweed to sea urchin grazing. Oecologia 82:217-226

Rohde S (2003) Chemische Verteidigung von Makrophyten der Ostsee: Interaktionen zwischen Primärproduzenten und ihren Konsumenten. MS thesis, University of Kiel

Editorial responsibility: Otto Kinne (Editor),

Oldendorf/Luhe, Germany
Schaffelke B, Klumpp DW (1998) Nutrient-limited growth of the coral reef macroalga Sargassum baccularia and experimental growth enhancement by nutrient addition in continuous flow culture. Mar Ecol Prog Ser 164: $199-211$

Schmitt TM, Hay ME, Lindquist N (1995) Constraints on chemically mediated coevolution: multiple functions for seaweed secondary metabolites. Ecology 76:107-123

Scrosati R (2002) Morphological plasticity and apparent loss of apical dominance following the natural loss of the main apex in Pterocladiella capillacea (Rhodophyta, Gelidiales) fronds. Phycologia 41:96-98

Soares AR, Teixeira VL, Pereira RC, Villaça R (2003) Variation on diterpene production by the Brazilian alga Stypopodium zonale (Dictyotales, Phaeophyta). Biochem Syst Ecol 31:1347-1350

Sotka EE, Taylor RB, Hay ME (2002) Tissue-specific induction of resistance to herbivores in a brown seaweed: the importance of direct grazing versus water-borne signals from grazed neighbors. J Exp Mar Biol Ecol 277:1-12

Steinberg PD, de Nys R, Kjelleberg S (2001) Chemical mediation of surface colonization. In: McClintock JB, Baker BJ (eds) Marine chemical ecology. CRC Press, Boca Raton, p 355-387

Teixeira VL, Pereira RC, Marques JA, Almeida S (1984) Estudo de populações de Codium decorticatum (Woodward) Howe em diferentes condições ambientais em Niterói (RJ). Annu IV Congr Soc Bot S Paulo, p 87-91

Toth GB, Pavia H (2000) Water-borne cues induce chemical defense in a marine alga (Ascophyllum nodosum). Proc Natl Acad Sci USA 97:14418-14420

Underwood A (1997) Experiments in ecology: their logical design and interpretation using analysis of variance. Cambridge University Press, Cambridge

Van Alstyne KL (1989) Adventitious branching as a herbivore-induced defense in the intertidal brown alga Fucus distichus. Mar Ecol Prog Ser 56:169-176

Van Alstyne KL, Pelletreau K (2000) Effects of nutrient enrichment on growth and phlorotannin production in Fucus gardneri embryos. Mar Ecol Prog Ser 206:33-43

Van Alstyne KL, Wolfe GV, Freidenburg TL, Neill A, Hicken C (2001) Activated defense systems in marine macroalgae: evidence for an ecological role for DMSP cleavage. Mar Ecol Prog Ser 213:53-65

Waite T, Mitchell R (1972) The effect of nutrient fertilization on the benthic alga Ulva lactuca. Bot Mar 15:151-156

Yates JL, Peckol P (1993) Effects of nutrient availability and herbivory on polyphenolics in the seaweed Fucus vesiculosus. Ecology 74:1757-1766

Submitted: February 3, 2004; Accepted: July 6, 2004 Proofs received from author(s): November 19, 2004 